\title{
Stomatal Control and Hydraulic Conductivity in 'Manzanilla' Olive Trees under Different Water Regimes
}

\author{
J.M. Torres-Ruiz, J.E. Fernández and A. Diaz-Espejo, Instituto de Recursos Naturales y \\ Agrobiología, IRNASE-CSIC, Apartado 1052, 41080-Sevilla, Spain.
}

M.J. Martín-Palomo and A. Morales-Sillero, Departamento de Ciencias Agroforestales, Universidad de Sevilla, 41013-Sevilla, Spain.

J.L. Muriel and R. Romero, IFAPA, Centro Las Torres-Tomejil, Ctra. Sevilla-Cazalla, km 12.2, 41200-Alcalá del Río, Sevilla, Spain.

Keywords: Olea europaea, localized irrigation, hydraulic conductivity, cavitation, embolism, xylem, stomatal conductance

\begin{abstract}
We studied the response of leaf water potential $\left(\Psi_{1}\right)$, stomatal conductance $\left(g_{\mathrm{s}}\right)$, leaf specific hydraulic conductivity $\left(K_{\mathrm{l}}\right)$ and percentage loss of hydraulic conductivity (PLC) in current-year shoots of 40-year-old 'Manzanilla' olive trees under three water treatments: Rainfed, in which rainfall was the only source of water; FAO, in which the trees were under localized irrigation to replace crop water demand; Pond, in which the whole root zone of the trees was maintained under non-limiting soil water conditions throughout the irrigation season. In the FAO trees, some roots were left in drying soil during the irrigation season. Results suggest near-isohydric behavior of olive trees. FAO trees maintained $\Psi_{1}$ values similar to those of Pond trees by increasing stomatal closure. In Rainfed trees, $g_{\mathrm{s}}$ values were smaller than in the irrigated trees, but stomatal closure did not prevent $\Psi_{1}$ values from falling below those of the irrigated trees, likely because of the dramatic decrease in soil water content observed in the Rainfed treatment. Values of $K_{1}$ and PLC showed no differences between treatments throughout the irrigation season. During that period, the PLC values ranged from $38 \%$ to $50 \%$, which shows that even the well-irrigated Pond trees were unable to maintain their hydraulic efficiency, likely because of the high atmospheric demand in the area.
\end{abstract}

\section{INTRODUCTION}

In trees with localized irrigation, some of the roots may be left in drying soil during the irrigation season. This can reduce stomatal conductance $\left(g_{\mathrm{s}}\right)$ in those trees as compared to others in which irrigation wets the entire root zone. This may occur even though the trees under localized irrigation are irrigated daily with enough water to replace crop evapotranspiration $\left(\mathrm{ET}_{\mathrm{c}}\right)$ (Fernández et al., 2003, 2009). The reduction in $g_{\mathrm{s}}$ may be due, at least in part, to changes in the hydraulic efficiency of the xylem caused by cavitation (Milburn, 1991). This was observed for Olea oleaster, among other species, by Lo Gullo et al. (2003), who worked with 2-year-old wild olive plants in pots. Raimondo et al. (2009) and Ennajeh et al. (2008) studied the hydraulic efficiency in current-year shoots of young olive trees in pots. As described by the cohesion-tension theory, water ascends in plants in a metastable state of tension, i.e., at negative pressure (Steudle, 2001). The relationship between that tension and the degree of embolism in the xylem conduits illustrates the hydraulic efficiency of the xylem (Cruiziat et al., 2002). The degree of embolism is characterized by the percentage loss of hydraulic conductivity (PLC). One of the most useful indices to describe the resistance of a 
species to xylem cavitation is the threshold xylem pressure at which loss of conductivity begins to increase rapidly, often referred to as the air entry pressure $\left(P_{\mathrm{e}}\right)$ (Meinzer et al., 2009).

The aim of this work was to evaluate the effect of different water treatments on leaf water potential $\left(\Psi_{1}\right), g_{\mathrm{s}}$, leaf specific hydraulic conductivity $\left(K_{1}\right)$ and PLC in current-year shoots of 40-year-old 'Manzanilla' olive trees growing in a semi-arid area of southern Spain. Results from this study were compared with previously obtained vulnerability curves to clarify aspects related to the hydraulic efficiency of the olive tree as influenced by water treatment.

\section{MATERIALS AND METHODS}

\section{Orchard Characteristics and Water Treatments}

The experiments were carried out in an experimental orchard with 40-year-old 'Manzanilla' olive trees at $7 \mathrm{~m} \times 5 \mathrm{~m}$ spacing $\left(37^{\circ} 17^{\prime} \mathrm{N}, 6^{\circ} 3^{\prime} \mathrm{W}, 30 \mathrm{~m}\right.$ a.s.1.). The climate is typical Mediterranean, with a mild, wet season from October to April; the rest of the year is hot and dry. Crop management and crop and soil characteristics are described elsewhere (Fernández et al., 2006).

In 2009, the orchard was divided into three different plots, each with a different irrigation treatment: 1) Rainfed, with rainfall as the only source of water supply; 2) FAO, in which the trees were irrigated daily from 6 May to 2 Oct at $100 \% \mathrm{ET}_{\mathrm{c}}$. Water was supplied with a lateral per tree row, five $3 \mathrm{~L} / \mathrm{h}$ drippers per tree, $1 \mathrm{~m}$ apart. This system left part of the roots in drying soil. The $\mathrm{ET}_{\mathrm{c}}$ values (Fig. 1) were calculated using the crop coefficient approach, as described by Fernández et al. (2006); 3) Pond, in which the trees were irrigated by a grid of pipes with a $2 \mathrm{~L} / \mathrm{h}$ dripper every $0.4 \mathrm{~m} \times 0.4$ $\mathrm{m}$. The grid covered a surface of $8 \mathrm{~m} \times 6 \mathrm{~m}$, with the tree in the middle, enough to maintain non-limiting soil water conditions for the entire root zone, throughout the irrigation season.

\section{Measurements}

On 23 Jun $[$ day of year $(\mathrm{DOY})=174), 28 \mathrm{Jul}(\mathrm{DOY}=209)$ and $25 \mathrm{Aug}(\mathrm{DOY}=$ 237), $g_{\mathrm{s}}$ was measured with a Li-6400 (Li-Cor, Lincoln, NE) in sunlit, well-developed leaves close to the apex of current-year shoots. Six leaves per treatment (two per tree from three representative trees) were sampled from $0830 \mathrm{~h}$ to $09.30 \mathrm{~h} \mathrm{GMT}$, when maximum values of $g_{\mathrm{s}}\left(g_{\mathrm{s} \max }\right)$ were recorded. Minimum daily values of $\Psi_{1}$ were recorded from $1300 \mathrm{~h}$ to $1400 \mathrm{~h}$ GMT, in the same number of leaves of the same type, with a Scholander chamber (Soilmoisture Equipment Corp., Santa Barbara, CA).

Hydraulic conductivity $\left(K, \mathrm{~m}^{4} / \mathrm{MPa} \mathrm{s}\right)$ in segments of current-year shoots was determined as described by Sperry et al. (1988), with a XYL'EM apparatus (Bronkhorst, Montigny les Cormeilles, France). Leaf areas distal to the shoot segments $\left(\mathrm{LA}, \mathrm{m}^{2}\right.$ ) were measured with a Li-3000C equipped with a $\mathrm{Li}-3050 \mathrm{C}$ (Li-Cor), to calculate the $K_{1}\left(\mathrm{~m}^{2} / \mathrm{MPa} \mathrm{s}\right)$ :

$$
K_{1}=K / L A
$$

The maximum vessel length in olive was estimated at $0.22 \mathrm{~m}$ by Lo Gullo and Salleo (1990). From each treatment, ca. 0.5-m long branches were sampled by cutting them under water to prevent air entry into the vessels. The branches were immediately sealed in double layers of black plastic bags with wet paper inside, to minimize dehydration and artificial embolism while transporting to the lab. The branches were 
sampled on the same days as the aforementioned $g_{\mathrm{s} \max }$ recordings. Five 3 -cm segments of current-year shoots per treatment were cut under water with a razor blade, debarked and connected to the XYL'EM apparatus. Filtered $(0.22 \mu \mathrm{m})$ and degassed $50 \mathrm{mM} \mathrm{KCl}$ solution was perfused with a pressure gradient of $3 \mathrm{kPa}$ to measure the initial $K_{1}$ ( $K_{1}$ ini $\mathrm{m}^{2} / \mathrm{MPa} \mathrm{s}$ ). Later, and to evaluate the degree of embolism in the samples, these were perfused with the same solution for $20 \mathrm{~min}$ at $0.15 \mathrm{MPa}$, which has been shown in previous measurements to suffice to remove any embolism. Then, $K_{1}$ was measured again at $3 \mathrm{kPa}$, to obtain the maximum $K_{1}\left(K_{1 \max }, \mathrm{m}^{2} / \mathrm{MPa}\right)$. The percentage loss of hydraulic conductivity (PLC) was determined as:

$$
\mathrm{PLC}=100\left(K_{1 \max }-K_{1 \text { ini }}\right) /\left(K_{1 \max }\right)
$$

The volumetric soil water content $\left(\theta_{\mathrm{v}}\right)$ in the soil of the three sampled trees per treatment was recorded every 7 to 10 days with a Profile probe (Delta-T Devices, Cambridge, UK) at 0.1, 0.2, 0.3, 0.4, 0.6 and $1.0 \mathrm{~m}$ depth and at 1,2 and $3 \mathrm{~m}$ from the trunk of each tree. These measurements were used to calculate the relative extractable water (REW) of the soil using the equation given by Granier (1987).

\section{RESULTS AND DISCUSSION}

Clear differences in REW were recorded between the Rainfed and irrigated treatments (Fig. 2). In both the FAO and Pond treatments, the soil was close to field capacity throughout the irrigation season. Decreasing values of REW were recorded in the Rainfed treatment, as expected.

Rainfed trees showed smaller $g_{\text {s max }}$ values than irrigated trees throughout the dry season (Fig. 3a). In July and August, smaller values of $g_{\mathrm{s} \text { max }}$ were recorded in the FAO trees than in the Pond trees, but the differences were not significant. The trends of $\Psi_{1}$ values recorded in the trees of each treatment (Fig. 3b) were similar to those of $g_{\mathrm{s} \text { max }}$ (Fig. 3a). Differences in $\Psi_{1}$ between the Pond and FAO trees were, however, smaller than those of $g_{\mathrm{s} \text { max. }}$. Measurements of $g_{\mathrm{s} \max }$ and $\Psi_{1}$ performed in the orchard by Fernández et al. (2009) during the dry season of 2007 yielded similar results, except that the $g_{\mathrm{s}}$ values were significantly lower in the FAO trees than in the Pond trees, indicating marked stomatal control in the trees with localized irrigation. This suggests nearisohydric behavior of the FAO trees, since they were able to maintain $\Psi_{1}$ values similar to those in the Pond trees by adjusting stomatal opening. This near-isohydric behavior has been described by Franks et al. (2007) for other species. In the Rainfed trees, stomatal control was not sufficient to prevent decreasing values of $\Psi_{1}$ (Fig. 3), likely because of the dramatic decrease in REW recorded in this treatment (Fig. 2).

Despite the observed differences in $\Psi_{1}$ and $g_{\mathrm{s} \text { max }}$ between treatments, similar values both of $K_{1}$ (Fig. 4a) and PLC (Fig. 4b) were found for all treatments throughout the experimental period. We determined a $P_{\mathrm{e}}$ value of $-1.43 \mathrm{MPa}$ using the vulnerability curves created for the trees in the orchard by Chamorro et al. (2007). Although we did not measure stem water potential $\left(\Psi_{\text {stem }}\right)$, the episodes of high atmospheric demand occurring in the area before and during the experimental period (Fig. 1) could have caused an occasional drop in $\Psi_{\text {stem }}$ values below $P_{\mathrm{e}}$ in the experimental trees of all treatments. This, in turn, might cause runaway embolism (Meinzer et al., 2009), which could then be responsible for the relatively high PLC values recorded in all trees (Fig. 4b). Cruiziat et al. (2002) reported that positive or close to positive $\Psi_{\text {stem }}$ values may be required to dissolve embolisms in xylem vessels. Data in Fig. 4, however, show that this was not sufficient for recovery of hydraulic efficiency in our 'Manzanilla' trees. In both FAO and Pond trees, near-zero $\Psi_{\text {stem }}$ values were recorded almost every day (data not 
shown), but the PLC values in both treatments ranged from $38 \%$ to $50 \%$ throughout the experimental period. It appears that if there is recovery of hydraulic efficiency, it must occur later in the season.

\section{ACKNOWLEDGEMENTS}

This work was funded by the Spanish Ministry of Education and Science, research project No.AGL2006-04666/AGR, and by the EU, research project ref. STREP 023120 .

\section{Literature Cited}

Chamorro, V., Durán, P., Infante, J.M. and Fernández, J.E. 2007. Características hidráulicas del ramo de olivo. En: Libro de Resúmenes del X Congreso Hispano-Luso de Fisiología Vegetal. Alcalá de Henares 18-21 Sep. p. 391.

Cruiziat, P., Cochard, H. and Ameglio, T. 2002. Hydraulic architecture of trees: main concepts and results. Ann. Forest Sci. 59:723-752.

Ennajeh, M., Tounekti, T., Vadel, A.M., Khemira, H. and Cochard H. 2008. Water relations and drought-induced embolism in olive (Olea europaea) varieties 'Meski' and 'Chemlali' during severe drought. Tree Physiol. 28:971-976.

Fernández, J.E., de la Torre, A., Morales-Sillero, A., Torres-Ruiz, J.M., Jimenez Bocanegra, J.A. and de Cires, A. 2009. Stomatal control by drying roots in olive trees under localized irrigation. Acta Hort. (in press).

Fernández, J.E., Díaz-Espejo, A., Infante, J.M., Durán, P., Palomo, M.J., Chamorro, V., Girón, I.F. and Villagarcía, L. 2006. Water relations and gas exchange in olive trees under regulated deficit irrigation and partial rootzone drying. Plant Soil 284:273291.

Fernández, J.E., Palomo, M.J., Díaz-Espejo, A. and Girón I.F. 2003. Influence of partial soil wetting on water relation parameters of the olive tree. Agronomie 23:545-552.

Franks, P.J., Drake, P.L. and Froend, R.H. 2007. Anisohydric but isohydrodynamic: seasonally constant plant water potential gradient explained by a stomatal control mechanism incorporating variable plant hydraulic conductance. Plant Cell Environ. 30:19-30.

Granier, A. 1987. Evaluation of transpiration in a Douglas-Fir stand by means of sap flow measurements. Tree Physiol. 3:309-319.

Lo Gullo, M.A. and Salleo, S. 1990. Wood anatomy of some trees with diffuse- and ring-porous wood: some functional and ecological interpretations. Giornale Botanico Italiano 124:601-613.

Lo Gullo, M.A., Salleo, S., Rosso, R. and Trifilò, P. 2003. Drought resistance of 2-yearold saplings of Mediterranean forest trees in the field: relations between water relations, hydraulics and productivity. Plant Soil 250:259-272.

Meinzer, F.C., Johnson, D.M., Lachenbruch, B., McCulloh, K.A. and Woodruff, D.R. 2009. Xylem hydraulic safety margins in woody plants: coordination of stomatal control of xylem tension with hydraulic capacitance. Funct. Ecol. 23:922-930.

Milburn, J.A. 1991. Cavitation and embolisms in xylem conduits. p. 163-174. In: A.S. Raghavendra (ed.), Physiology of Trees. Wiley, New York.

Raimondo, F., Trifilo, P., Lo Gullo, M.A., Buffa, R., Nardini, A. and Salleo, S. 2009. Effects of reduced irradiance on hydraulic architecture and water relations of two olive clones with different growth potentials. Environ. Exp. Bot. 66:249-256.

Sperry, J.S., Donnelly, J.R. and Tyree, M.T. 1988. A method for measuring hydraulic conductivity and embolism in xylem. Plant Cell Environ. 11:35-40. 
Steudle, E. 2001. The cohesion-tension mechanism and the acquisition of water by plant roots. Ann. Rev. Plant Physiol. Mol. Biol. 52:847-875. 


\section{Figures}

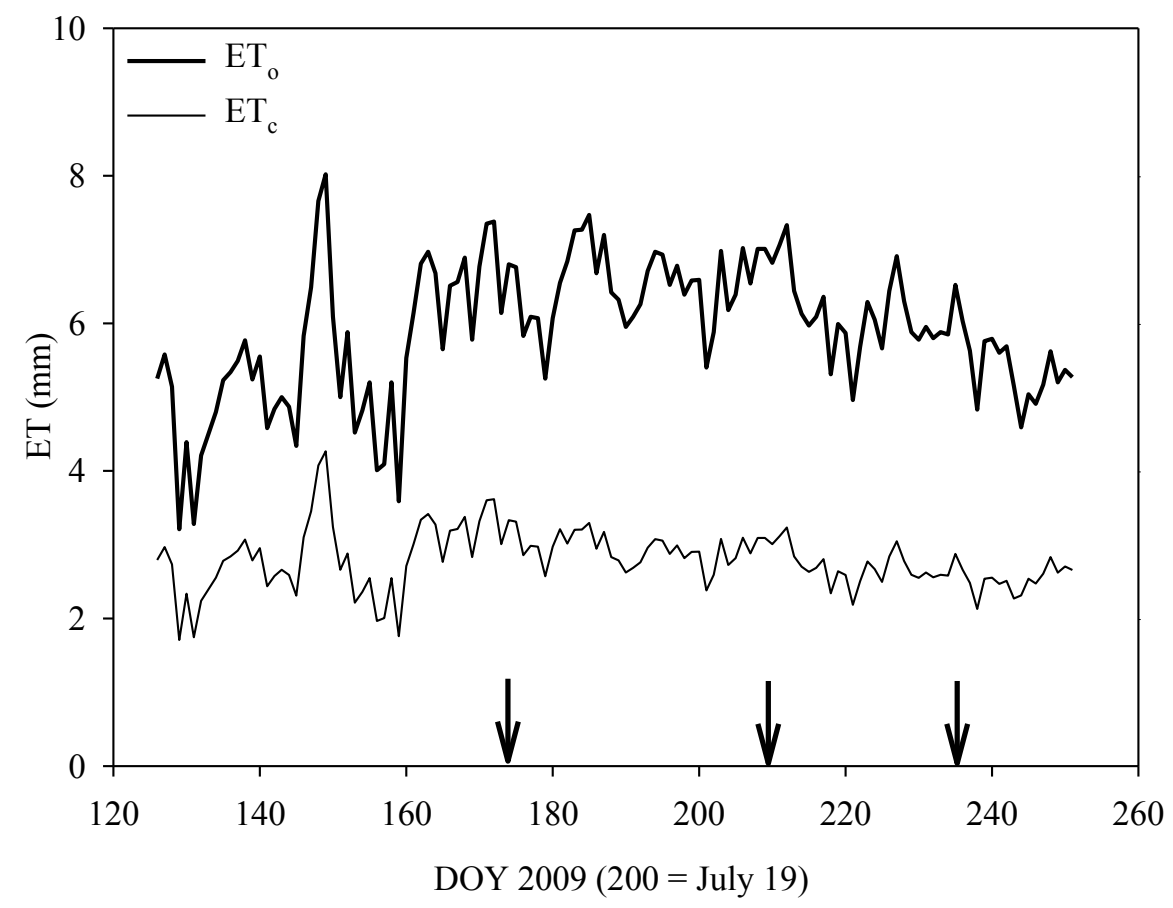

Fig. 1. Time course of potential $\left(\mathrm{ET}_{\mathrm{o}}, \mathrm{mm}\right)$ and crop $\left(\mathrm{ET}_{\mathrm{c}}, \mathrm{mm}\right)$ evapotranspiration in the olive orchard during the irrigation period. DOY $=$ day of year. Arrows indicate sampling dates.

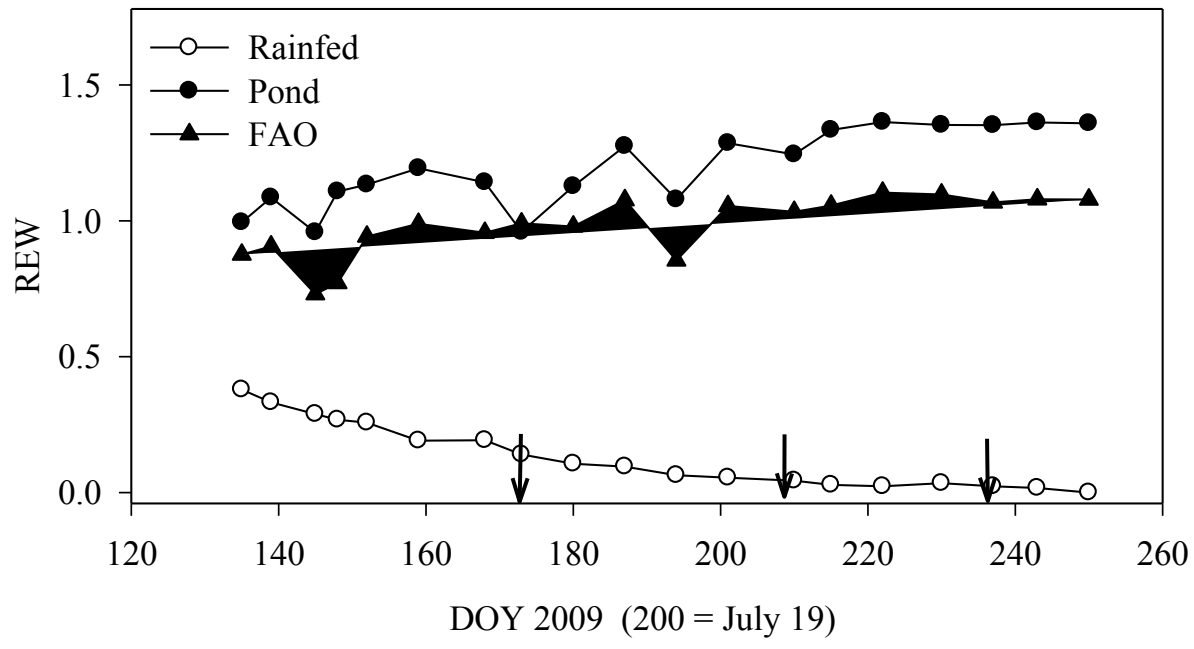

Fig. 2. Time course of relative extractable water (REW) in the soil of each treatment during the irrigation period. DOY $=$ day of year. Arrows indicate sampling dates. 


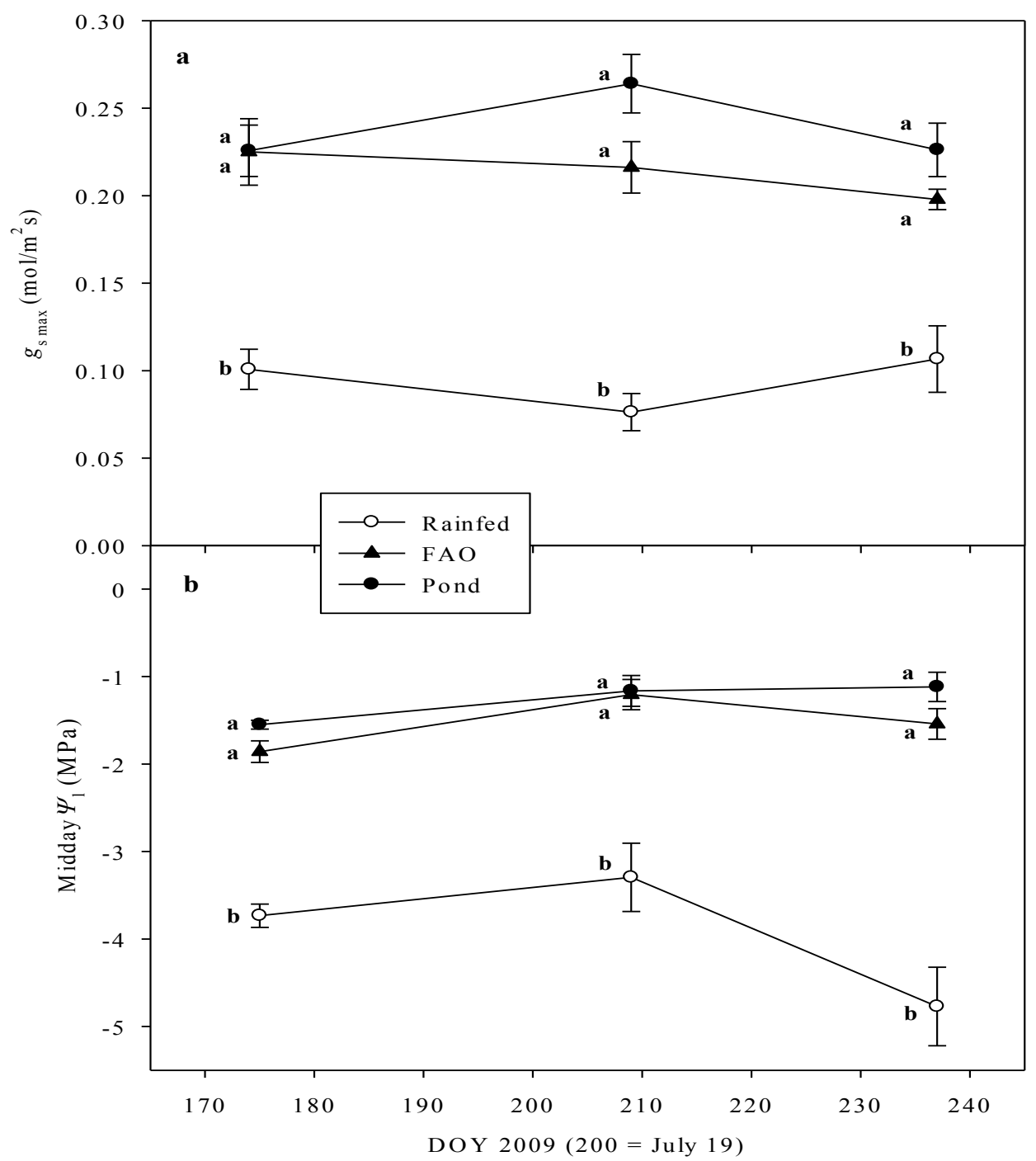

Fig. 3. Time course of maximum stomatal conductance $\left(g_{\mathrm{s} \max }\right)$ (a) and midday leaf water potential $\left(\Psi_{1}\right)(\mathrm{b}) . \mathrm{n}=3-5 \pm \mathrm{SE}$. Mean values with different letters are significantly different at $P \leq 0.05$. DOY $=$ day of year. 


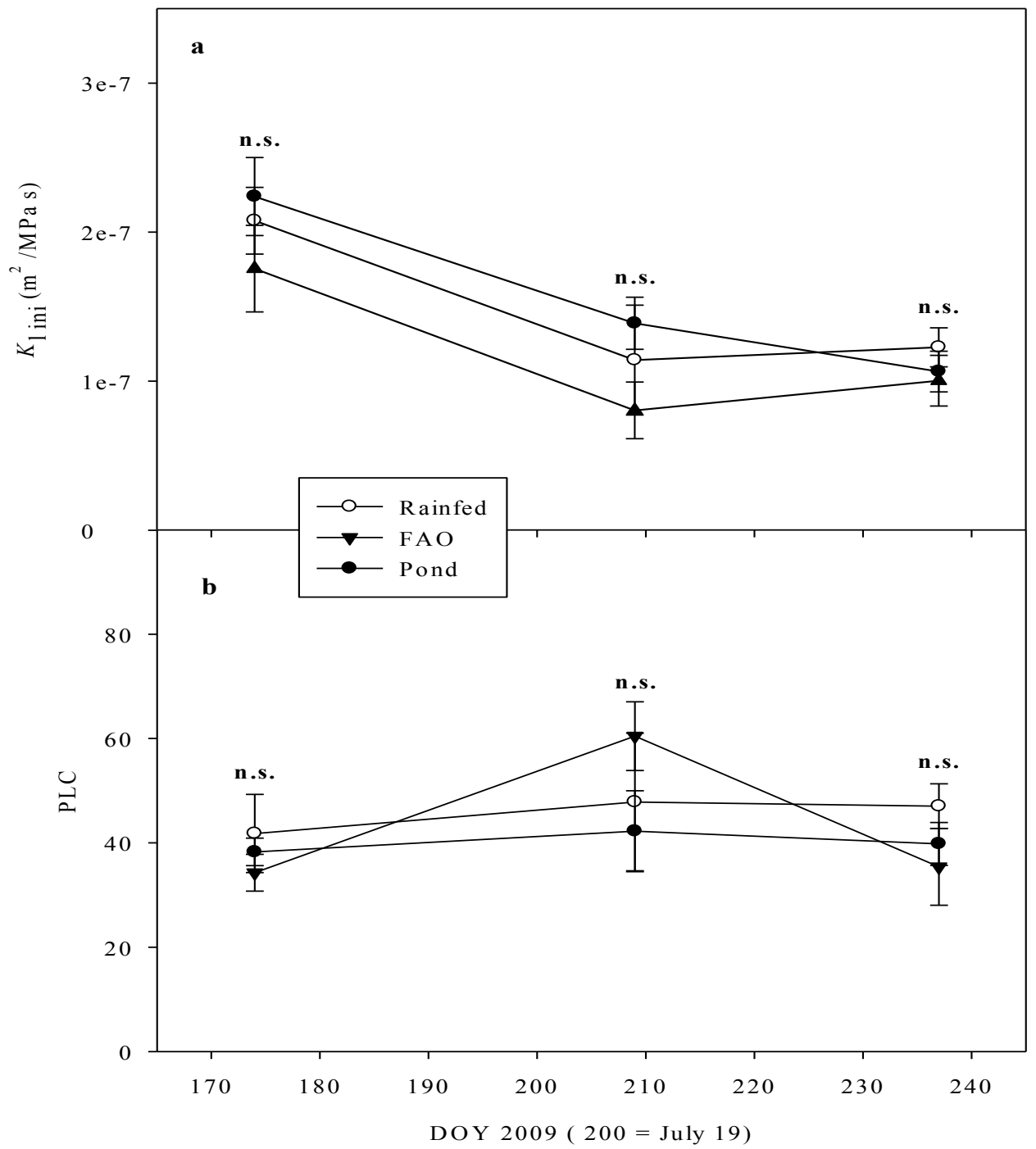

Fig. 4. Time course of initial leaf specific hydraulic conductivity $\left(K_{1}\right.$ ini $)$ (a) and of percentage loss of hydraulic conductivity (PLC) (b). $\mathrm{n}=3-5 \pm$ SE. n.s. $=$ no significant difference. DOY $=$ day of year. 